\title{
2 Greenhouse gas emissions from a Western Australian finfish supply chain
}

3 Felicity Denham ${ }^{\mathrm{a} 1}$, Wahidul Biswas ${ }^{\mathrm{b}}$, Vicky A. Solah ${ }^{\mathrm{c}}$ and Janet Howieson ${ }^{\mathrm{a}}$

$4 \quad{ }^{a}$ Centre of Excellence Science Seafood and Health, Faculty of Health Sciences, Curtin

5 University, GPO Box U1987, Perth, Western Australia 6845

$6 \quad{ }^{b}$ Sustainable Engineering Group, Curtin University, GPO Box U1987, Perth 6845, Western

$7 \quad$ Australia, Australia

$8{ }^{c}$ School of Public Health, Faculty of Health Sciences, Curtin University, GPO Box U1987,

$9 \quad$ Perth 6845, Western Australia, Australia.

10 Keywords

- Greenhouse gas

- Finfish supply chain

- Life cycle assessment

\section{Abstract}

Greenhouse gas $(\mathrm{GHG})$ emissions in the form of carbon dioxide equivalent $\left(\mathrm{CO}_{2}-\mathrm{eq}\right)$ from two Western Australian finfish supply chains, from harvest to retail outlet, were measured using streamlined life cycle assessment methodology. The identification of interventions to potentially reduce the GHG emissions was determined from the results obtained. Electricity consumption contributes to the highest GHG emissions within the supply chains measured, followed by refrigeration gas leakage and disposal of unused fish portions. Potential cleaner production strategies (CPS) to reduce these impacts include installing solar panels, recycling the waste, good housekeeping in refrigeration equipment maintenance, and input substitution of refrigeration gas. The results show a combination of these strategies have the potential to reduce up to $39 \%$ of the total GHG emissions from fillet harvest, processing and retail.

\section{Introduction}

The atmospheric concentration of greenhouse gases (GHG), including carbon dioxide $\left(\mathrm{CO}_{2}\right)$, methane $\left(\mathrm{CH}_{4}\right)$ and nitrous oxide $\left(\mathrm{N}_{2} \mathrm{O}\right)$, is increasing (Forster et al., 2007). Airborne particles in the gases then absorb more heat, thus resulting in global warming which causes climate change (Forster et al., 2007). To minimise potential increases in temperature, primary

30 industries that release GHG (such as the seafood industry) should apply cleaner production strategies (CPS) to combat climate change (UNEP, 2002). This paper focusses on the global

\footnotetext{
${ }^{1}$ Corresponding author email address: f.denham@curtin.edu.au
} 
warming impact of the resources utilised in two Western Australian seafood supply chains by calculating the GHG per tonne $(\mathrm{t})$ of fish fillets.

Streamlined life cycle assessment (SLCA), following the steps of International Organisation for Standardization (2006) is the most widely used method for measuring the upstream GHG emissions only, not taking into account the complete product life cycle (Biswas et al., 2010; Engelbrecht et al., 2013; Gunady et al., 2012). Its application models the GHG emissions for the current study.

Numerous studies have concentrated on modelling GHG emissions and other environmental impacts from harvesting fish (Table 1). However, none of these studies includes data from Western Australia where water temperature, fish species, vessel types and logistics, particularly the long distances from port to fishing ground, differ from other countries.

Several SLCA studies have also investigated the environmental impacts of different transport methods of fish once landed to determine the most environmentally friendly and economic system. Studies included the impact of transporting methods for fresh (never been frozen) and frozen fish (Andersen, 2002; Vázquez-Rowe et al., 2012) and comparing truck (Andersen, 2002; Kissinger, 2012; Tlusty and Lagueux, 2009; Vázquez-Rowe et al., 2012), air (Andersen, 2002; Tlusty and Lagueux, 2009; Vázquez-Rowe et al., 2012), boat (Andersen, 2002; Kissinger, 2012; Vázquez-Rowe et al., 2012), and rail (Kissinger, 2012) transportation methods. However, Western Australia's case differs from these studies as in some cases fish is transported over 2,000 $\mathrm{km}$ from the port to the nearest capital city (Department of Fisheries, 2012).

This study is also unique in combining the three supply chain stages in finfish production: harvesting, processing and retailing. The process in environmental supply chain management requires all stakeholders in a supply chain to work together to measure the impact and identify strategies to attain economically viable outcomes with low GHG emissions (Gupta and Palsule-Desai, 2011). Sustainable seafood supply chain management is working as a whole supply chain with the intention of reducing life cycle environmental impact, enhancing social equity and reducing operational costs therefore increasing profit. In seafood supply chains, previous environmental research studies have only focussed on the harvest (Iribarren et al., 2011; Svanes et al., 2011b; Vázquez-Rowe et al., 2011b; Ziegler et al., 2011), processing (Bezama et al., 2012; Hospido et al., 2006; Williams and Wikström, 2011 ) and transport stages (Coley et al., 2011; Tlusty and Lagueux, 2009) in the supply chain; only Winther et al. (2009) and Ellingsen et al. (2009) followed harvest through to value adding, but ignored the retail stage. Thus a combination of the whole Western Australian seafood supply chain GHG emissions provides a more effective picture of environmental supply chain management.

Food LCA studies specific to Australia follow a similar trend with only $6 \%$ covering the retail stage within the supply chain (Renouf and Fujita-Dimas, 2013). Only Hobday et al. (2014) covered the whole seafood supply chain in Australia, but did not cover the species and transport distances associated with Western Australian finfish. 
To fill these gaps of the Western Australian finfish industry knowledge and add to the whole supply chain research, this study has aimed to analyse the Western Australian finfish supply chain's GHG from harvest to retailer. The specific objectives were to:

a) assess the global warming impact of the harvest, processing and retail stages of two Western Australian finfish supply chains using a SLCA method;

b) identify the 'hotspots' or the inputs and outputs emitting the highest amount of GHG during the life cycle of the finfish product; and

c) recommend opportunities for possible GHG CPS.

\subsection{Description of finfish supply chains examined}

The fish was trawl harvested in the North Coast Bioregion as described by The Department of Fisheries (2012). The boat travelled approximately $200 \mathrm{~km}$ from port before trawling started. The post-trawl fish process included emptying the catch into a hopper, sorting by size into baskets (or polypropylene bags for large fish), cooling in seawater brine for four hours and packing into tubs for cool room storage once the fish reached $0^{\circ} \mathrm{C}$. Once the boat arrived at port after ten days at sea, the fish were packed onto pallets by species and unloaded off the boat, onto a truck. The boat underwent cleaning and maintenance before it returned to sea.

City retailers handle a larger quantity than the regional retailers so, from the landing of the harvested fish, two supply chains were chosen for this SLCA analysis, one to a city retailer and one to a regional retailer. The city retailer was located more than $1,000 \mathrm{~km}$ away from the landing port whereas the regional retailer was within $20 \mathrm{~km}$.

- The city retailer processed the fish into fillets on site as required, instead of using a dedicated filleting processing facility.

- The regional processor filleted, packaged and transported fillets to local and surrounding restaurants and the regional retail outlet.

Hence, in summary there were two separate supply chains from landing: chain one with three firms - harvesting, regional processing and regional retailing; and chain two with two firms harvesting and city retailing. The system boundaries of this research (Figure 1) included transportation of all consumable items to their respective stages and fish waste disposal to landfill. The system boundaries of the proposed SLCA excluded all downstream activities, including food service and restaurant sectors and handling after the product left the retail facility.

As seafood handled in the processing and retail facilities includes other seafood products (e.g. crustaceans), an allocation procedure separated inputs for the finfish products by weight. The inputs allocated included power, water and refrigeration gases as data provided was per facility.

The selected trawl firm provides $20.5 \%$ of the finfish from the North Coast Bioregion (Department of Fisheries, 2012) where $73 \%$ of the finfish in this region was trawl caught. The species in this region differ from other regions in Western Australia, as the large 
110 coastline results in various water temperatures throughout Western Australia. Therefore, this

111 study is representative of firms dealing with species such as Crimson snapper (Lutjanus

112 erythropterus), Bluespotted emperor (Lethrinus punctulatus) and Rosy threadfin bream

113 (Nemipterus furcosus).

114 From this capture, $8.7 \%$ of the fish caught are utilised in the regional processor and $5.9 \%$ in

115 the city retailer. The remaining fish is sold to a private processor. Although these supply

116 chains are only a sample of Western Australia's seafood industry, the framework can still be

117 applied in other companies. The study covers the supply chain from capturing the fish, to

118 leaving the retail store, including typical trawling, processing and retailing processes with

119 similar inputs and outputs. The only items that may differ from other Western Australian

120 fresh finfish supply chains are the transport distances of both consumable items to site and

121 fish to processor or retailer, and the method of packaging (whether fillets are packed loosely

122 in carton liners as per the regional processor or if they are vacuum packed). These variations

123 are beyond the scope of this research.

\section{Standard methods for streamlined life cycle assessment}

125 The GHG emissions from the Western Australian test seafood supply chain was benchmarked 126 using a streamlined approach, as it did not take into account downstream activities such as

127 fish consumption. This SLCA approach undertaken followed the four steps of International

128 Organisation for Standardization (2006): goal, life cycle inventory, impact assessment and

129 interpretation. The goal was to ascertain the GHG emissions from the Western Australian

130 finfish supply chain. The functional unit was one tonne of processed fish sold at retail. This

131 unit was used to determine the number of stages of fish life cycle for developing an

132 inventory. The inputs (i.e. chemicals, energy) and outputs (i.e. emissions from processes)

133 were quantified for each life cycle stage for developing inventories of one tonne of processed

134 fish sold at retail for city and retailer supply chains. Some of the data for developing

135 inventories came from field survey, while the rest of the data was obtained from literature.

136 Collaborating firm interviews occurred between August 2012 and September 2013 and were

137 compiled in a life cycle inventory (LCI) spreadsheet. The LCI considers all the relevant

138 inputs and outputs for processes that occur during the life cycle of a product. Inventory data

139 was categorised into consumable items, energy, transport, storage and waste (Table 2).

140 Preliminary data for LCI: Representatives from each of the supply chain stages, including a 141 trawler off the coast of regional Western Australia, a regional processor, a regional retailer 142 and a city retailer were interviewed face to face to obtain primary information using a 143 structured questionnaire.

144 The harvest data includes the quantity of fish harvested, diesel and boat maintenance required 145 per year.

146 The processing and retail data included the quantity of fish purchased, fish waste and its final

147 destination to landfill, electricity and water consumption, consumable materials and the

148 distances all travelled to the site. 
Secondary data for LCI: Secondary data included different data sources:

- international literature provided data estimation from elements that were not possible to collect from the field (i.e. refrigeration gas leakage);

- medical safety data sheets for chemical quantities;

- national reports for waste emission recovery and bioelectricity production; and

- international databases to calculate the eco-inventories of raw materials and energy sources (i.e. packaging materials, gloves, chemicals, boat maintenance and paper).

Once the inventory has been developed using both primary and secondary data sources, emission factors for all inputs and outputs were developed for assessing the life cycle GHG emissions of one tonne of fish fillets sold at retail.

Each $\mathrm{CO}_{2}, \mathrm{CH}_{4}$ and $\mathrm{N}_{2} \mathrm{O}$ gas emission from the LCI was developed. The inputs and outputs of the LCI were multiplied by the respective emission factors (Table 3). Energy emission factors were applied to consumable materials when only an energy breakdown analysis was available. Once the inputs were estimated for the production of one tonne of fish fillets sold at retail, then these inputs were multiplied by their respective emission factors. These emission factors were mainly sources from the local databases. In the absence of the local database, new emission data base were created for the inputs (e.g. battery emissions (Lankey and McMichael, 2000; Life Cycle Strategies Pty Ltd, 2012)).

Energy emission factors: Energy included electricity, diesel, steam, LPG, natural gas, crude oil, coal and petroleum and was calculated from Life Cycle Strategies Pty Ltd (2012). These emission factors were also used for consumable materials when only an energy breakdown analysis was available. The energy breakdown for batteries was taken from Lankey and McMichael (2000).

Storage emission factors: Storage included ice production and refrigeration. All refrigeration gas emission factors were calculated using the leakage rates from The Australian Institute of Refrigeration (2012) (30\% for boats, $12.5 \%$ for walk in cool rooms and $12.5 \%$ for display cabinets) and the emission factor from The Department of Sustainability, Environment, Water, Population and Communities (2012) (Table 3). The ice machine energy breakdown and the water and refrigerant quantities contributed to the ice emission factor.

Transportation emission factors: Transportation included of transportation of consumables and fish each facility and was calculated from Life Cycle Strategies Pty Ltd (2012) for ship, international airfreight, articulated truck, car, light commercial vehicles and rail transportation. The refrigerated truck had 20\% more energy (Tassou and Ge, 2008).

Waste emission factor: The waste emissions from unused fish portions in this research including heads, viscera, scales, bones, tails etc. were calculated to be $1.39 \mathrm{~kg} \mathrm{of} \mathrm{CO}_{2}$-eq per $\mathrm{kg}$ of fish using the Buswell equation (Symons and Buswell, 1933), composition of the waste (Esteban et al., 2007; Khoddami, 2012; Ng, 2010) and anaerobic digestion yields (Curry and Pillay, 2012; Davidsson et al., 2007) to calculate the methane emitted to the atmosphere, instead of harvested for energy. Although some landfill sites in Western Australia are 
harvested for methane, the average of 38.9\% of $\mathrm{CH}_{4}$ recovered from landfill (Department of the Environment) and the resulting $502 \mathrm{kWh}$ of energy per functional unit (Clean Energy Council, 2013) was included in the waste emission factor.

Finally, following IPCC's fourth assessment report (Forster et al., 2007), all GHGs associated with the production of one tonne of fish fillets sold at retail were converted to 100 year impacts in $\mathrm{kg}$ of $\mathrm{CO}_{2}-$ eq.

After the SLCA, CPS were assessed to mitigate supply chain GHG emissions. These five categories of strategies are described further in UNEP (2002) and van Berkel (2007):

1. Good housekeeping

2. Input substitution: replacing resources with environmentally preferred substances

3. Technological modification: modifying existing structures to increase efficiency

4. Product modification: modifying a product to reduce material consumption and to enhance recyclability

5. Recycling waste.

\section{Results and Discussion}

\subsection{Comparison of the city and regional supply chains}

Although both supply chains include transporting the fish from the port, filleting and storage, the supply chain's inventories differed (Table 4). The regional supply chain had an extra stage and the city supply chain consumed more electricity due to a larger and potentially more inefficient refrigeration system (The city supply chain consumed more than six times the electricity consumed in the regional supply chain). The city supply chain also had more tkm (tonnes $\mathrm{x} \mathrm{km}$ travelled) of refrigerated transport to get the fillets to the retailer due to the large distance from port.

Producing one tonne of fish fillets released a total of $18,870 \mathrm{~kg} \mathrm{CO}_{2}$-eq from the regional supply chain and $92,560 \mathrm{~kg} \mathrm{CO}_{2}$-eq from the city supply chain (Figure 2). The Monte Carlo Simulation was run to determine the mean, standard deviation and standard error of the mean from each supply chain (Table 5). The standard deviations were only $2.8 \%$ and $3.9 \%$ of the mean values of the carbon footprint of the regional and city supply chains, respectively, confirming the validity of this LCA.

\subsection{Identification of hotspots}

Relative impacts from the various supply chain components are shown in Figure 3. The greatest GHG emissions within the two supply chains measured were from energy (mainly electricity consumption (78\% in the regional supply chain and $93 \%$ in the city supply chain) followed by refrigeration gases ( $11 \%$ in the regional supply chain and $4 \%$ in the city supply chain) and filleting waste (6\% in the regional supply chain and $1 \%$ in the city supply chain). 
Energy consumption was also the hotspot in other seafood LCA studies, however, in this study, the energy use was from electricity used in processing and retail, rather than diesel consumption in the harvest stage as found by Winther et al. (2009), Thrane (2004), and Vázquez-Rowe et al. (2010b, 2011b).

Whilst the supply chains measured required long distant transport $(>1,000 \mathrm{~km})$, the transportation had a minimal impact in the regional $(1.1 \%)$ and city $(0.05 \%)$ supply chains. This is because each consumable purchased had a relatively low weight, resulting in a low tkm. Transport of fish to the city retail outlet had a larger impact than transporting the consumable items to the boat, regional processor and regional retailer.

232 When comparing these results to previously published work, few studies had the same areas of greatest impact perhaps because they did not include the whole supply chain (Ellingsen et al., 2009; Svanes et al., 2011b; Vázquez-Rowe et al., 2013; Winther et al., 2009; Ziegler et al., 2013), excluded refrigeration gases (Iribarren et al., 2010; Thrane, 2006; Vázquez-Rowe et al., 2011b) or the supply chains did not use refrigerants with a high GHG emission factor (Winther et al., 2009). Previous seafood LCA studies either focussed on the harvest supply chain stage, where energy use was diesel (Ellingsen and Aanondsen, 2006; Svanes et al., 2011a; Winther et al., 2009) or focussed on the processing and retail stages that require electricity used in processing (Vázquez-Rowe et al., 2013; Winther et al., 2009).

If this study excluded the refrigerant leakage, the emissions would be underestimated by $11 \%$ and $4 \%$ from the regional and city supply chains respectively. Vázquez-Rowe et al. (2013), Ziegler (2013) and Svanes (2011b) found refrigerant leakage to be a hotspot during harvest but did not measure beyond harvest into processing and further handling. Although Iribarren (2010) originally did not include refrigerants in his research, in a later study he found refrigerant leakage to have the greatest carbon emissions from fish capture (Iribarren et al., 2011). Other studies including Thrane (2006) and Vázquez-Rowe (2011b) ignored refrigeration completely in their research. Winther (2009) did include refrigerants, but the study comprised of carbon neutral alternatives. As a result, the energy used in the harvest was the hotspot (Thrane, 2006; Vázquez-Rowe et al., 2011b; Winther et al., 2009; Ziegler et al., 2013) with minimal GHG from processing and retail. None of these aforementioned studies included fish waste.

\subsection{Potential cleaner production strategies}

254

255

256

257

258

259

260

261

As the three greatest GHG hotspots within both supply chains were energy from electricity, refrigeration gas leakage from the cool rooms, ice machines, and display cabinets, and the breakdown of fish waste in landfill, potential CPS are discussed. These include installing solar panels (an input substitution CPS as it is associated with the replacement of conventional electricity solar electricity), the conversion of fish waste to bio-electricity (input substitution, technological modification or recycling CPS) and reducing the GHG emissions from refrigerant leakage equipment (a good housekeeping CPS).

\subsection{1. $\quad$ Solar electricity}


Electricity as a hot spot is related to refrigeration and low temperatures are required to keep fish food-safe. Other LCA studies in the food industry have found a similar energy hotspot including Sanjuan et al. (2014), Vázquez-Rowe et al. (2013) and Winther et al. (2009). As most of the energy consumption from the supply chains measured in this study is electricity, there is the opportunity of harvesting solar energy as a potential CPS.

267 Solar energy (an input substitution CPS) is useful for supplementing the bulk of the power used during the day. As the energy consumption from the partnering firms was from refrigeration and freezing non-fish products, it is assumed energy consumption is consistent over a 24 hour period. Therefore, solar panels can be used to supplement grid electricity during the peak sun hours of the day. Peak sun hours are the time per day the sun provides the maximum solar energy, differing in various locations around Australia and in different seasons of the year. The average peak sun hours were calculated from BOM (2013) for both the regional processer and city retailer regions. The solar emission factor was taken from Lund and Biswas (2008) (multicrystalline solar system at $0.075 \mathrm{~kg}$ of $\mathrm{CO}_{2}$-eq per $\mathrm{kWh}$ ). Due to the total energy consumption, a $20 \mathrm{~kW}$ and a $100 \mathrm{~kW}$ system is recommended for the regional processor and the city retailer respectively, resulting in a potential GHG emission reduction of $17.1 \%$ and $21.3 \%$ respectively. Although a $20 \mathrm{~kW}$ and a $100 \mathrm{~kW}$ system will cost $\$ 2,919$ and $\$ 13,365$ per tonne of fillets, it will potentially reduce the electricity bill by $\$ 1,071$ and $\$ 7,377$ per tonne of fillets per year in the regional processor and the city retailer respectively (Shetty, Personal Communication), resulting in a payback period of less than three years for the regional supply chain and two years for the city supply chain.

\subsubsection{Biogas electricity}

284 The filleting waste may also be utilised for biogas (a technological modification and recycling waste CPS), providing a second alternative to grid electricity consumption. Using the Buswell Equation (Symons and Buswell, 1933) and the amino and fatty acid breakdown of the fish species from Western Australia (Esteban et al., 2007; Khoddami, 2012; Ng, 2010), the $\mathrm{CO}_{2}, \mathrm{CH}_{4}$, ammonia $\left(\mathrm{NH}_{3}\right)$ and hydrogen sulphide $\left(\mathrm{H}_{2} \mathrm{~S}\right)$ from the anaerobic digestion process can be predicted.

290 Although the Buswell Equation assumes complete digestion, it can be used to predict the quantity of potential $\mathrm{CH}_{4}$ production. Both Davidsson et al. (2007) and Curry and Pillay (2012) calculated the actual methane yield compared to the predicted yield of municipal waste and found $76.7 \%$ and $74.9 \%$ respectively. If the average $(75.8 \%)$ is applied to this study, processing all the filleting waste would produce $85.57 \mathrm{~kg}$ of $\mathrm{CH}_{4}$ (Table 6), resulting in $4,757 \mathrm{MJ}$ of energy per functional unit in both supply chains. However, if converted to electricity using a generator, only $46 \%$ of the energy is converted (Reedman, Personal

297 Communication), leaving $607.9 \mathrm{kWh}$ per functional unit, theoretically preventing a potential

$298 \quad 15.2 \%$ and $3.1 \%$ of total emissions from the city and regional supply chains respectively.

299 As the firms in this study produce other products, the energy production from fish waste 300 production would only supply $0.62 \%$ and $3.75 \%$ of the total energy consumed by the city 301 retailer and regional processor respectively, saving \$1 598 and \$2 071 per year. As the 
system would require both a digester such as a stainless steel IBC ( $\$ 2850)$ and a generator to convert the gas to electricity ( $\$ 11500)$, the potential electricity savings would take nine years and seven years to recover costs from the city retailer and regional processor respectively, making biogas a less efficient investment for the potential GHG and electricity cost reductions compared to the solar electricity option.

\subsection{3. $\quad$ Refrigeration Modification}

The refrigeration emissions as a hotspot in this research, was a hotspot in other food industries including fresh pineapple (Ingwersen, 2012), fish on the boat (Svanes et al., 2011b; Vázquez-Rowe et al., 2013; Ziegler et al., 2013), ice cream (Australian Industry Group, 2011) and butter (Büsser and Jungbluth, 2009). Thus, GHG from refrigeration is not just a seafood issue. However, none of these studies offered potential CPS other than increasing maintenance to reduce the impact.

Equipment maintenance, a 'good housekeeping' CPS, is one method to reduce the GHG emissions from refrigeration. Although the equipment in the current study is regularly serviced, any lapse can increase the current leakage by $2.5 \%$ from the display cabinets and walk-in cool-rooms used by the regional processor, regional retailer and city retailer (The Australian Institute of Refrigeration, 2012). Therefore, applying this potential $2.5 \%$ savings to the supply chains measured by simple good housekeeping CPS potentially prevents an estimated $0.28 \%$ and $0.10 \%$ of GHG emissions from the regional and city supply chains respectively.

Another method of reducing the impact of the refrigeration gas GHG in the studied supply chains is to change the refrigerant used (both a 'technological modification' and 'input substitution' CPS). The supply chain partners have recently converted their systems from R22 to the more 'environmentally friendly' R404a refrigerant. Although there are refrigeration gases with little or no GHG available such as ammonia, which would eliminate GHG emissions from refrigeration (ICF Consulting, 2003), refrigerant changes are expensive, particularly when the current R404a systems in the supply chains measured are new. For example, a quote for Sydney Fish Markets to change their refrigerants from R22 to HFC134a would potentially cost $\$ 255.22$ per tonne of seafood (Northern Prawn Fisheries, 2014; Sydney Fish Market, 2013). This cost included updating the plant, evaporators, pipework and warm glycol defrost, warm glycol circulation to replace door heater, labour, electrical and controls, refrigerant, contractors costs, contingency and warranty (Northern Prawn Fisheries, 2014). As changing the refrigerant requires complete equipment replacement, it is an expensive project that is unlikely to occur until the current refrigeration units require replacing.

Although changing the refrigerant would improve each supply chain's GHG emissions by up to $11.3 \%$ and $4.0 \%$ in the regional and city supply chains respectively, the capital cost of updating the equipment without any resultant change in profit is a barrier to change. 
340 In summary, the GHG emissions from refrigerants can potentially be reduced using good

341 housekeeping, technological modification and input substitution. Such changes can potentially reduce the total GHG emissions by up to $11.3 \%$ (Figure 4 ).

\subsubsection{Utilising waste}

344 In the supply chains measured, there was $62.5 \%$ (by weight) wastage from filleting fish. By isolating this waste during processing and developing by-products from the specific waste streams, resources efficiency may increase by 'recycling' the waste, which is one of the CPS. Biogas production has already been discussed, but further possibilities for waste usage include fertiliser and hydrolysate.

349 Fish waste can be composted into fertiliser for a possibly inexpensive solution. López-

350 Mosquera et al. (2011) composted the fish waste with seaweed and sawdust, applying their composting method to the waste from Western Australia could potentially reduce the GHG by $6.0 \%$ and $1.2 \%$ from the regional and city supply chains respectively.

Fish waste is also a good source of hydrolysate (fish ground into liquid) that can be used for protein powders, fertiliser, and animal feeds. Aspmo et al. (2005) and Bhaskar and Mahendrakar (2008) only used the viscera and thus, only used $10.3 \%$ of the waste product. However, when all the fish waste is used as in Nges et al. (2012), the GHGs would potentially reduce by $6.0 \%$ and $1.2 \%$ from the regional and city supply chains respectively.

There are barriers to recycling waste that affect both supply chains. Firstly, the cost to transport the waste over $1000 \mathrm{~km}$ to the nearest capital city for processing is a major barrier. Secondly, many of the suggestions above require the purchase of capital equipment to convert waste to biogas, fertiliser or hydrolysate. Thirdly, due to the current size of both the regional processor and city retailer, a new premise will also be required for each supply chain to manufacture these recycled products, or potentially outsource them. Thus, further research is required into the feasibility, cost and exact GHG reduction in each supply chain in Western Australia.

Another consideration is that whilst reusing the all the fish waste to create another product can potentially reduce the current GHG emissions by up to $6.0 \%$ (Figure 4), these calculations do not account for the GHG in producing the waste products (e.g. electricity consumption). Thus, further research is required into the GHG potential in recycling fish waste.

\subsection{Overall improvement opportunities}

372 Overall, if all CPS discussed were applied - installing solar power, maintaining equipment, 373 changing the refrigerant and recycling the fish waste,- the current GHG emissions would reduce potentially by $38.6 \%$ and $25.7 \%$ from the regional and city supply chains respectively

375 (Figure 4). If extrapolated to the total fish quantity from the North Coast Bioregion, this 376 would be equivalent to a potential savings of 4.9 million tonnes of $\mathrm{CO}_{2}$-eq from the regional supply chain or 16 billion tonnes of $\mathrm{CO}_{2}$-eq from the city supply chain's processes. 
378 The two supply chains measured differed mainly in their electricity consumption per

379 functional unit. Although the city supply chain has more significant improvement

380 opportunities through the CPS discussed, the regional supply chain has significantly lower

381 GHG emissions. The regional supply chain has greater opportunity for reducing its current

382 GHG emissions, particularly harvesting solar energy. Although recycling filleting waste into

383 biogas does reduce grid electricity consumption, it is expensive for the quantity of electricity

384 generated. Therefore, installation of solar energy is recommended. The city supply chain had

385 more GHG emissions, particularly as the retailer had a large electricity consumption.

386 Both supply chains have the same barriers to solar energy installation. Although harvesting

387 solar energy in both supply chains will reduce both GHG emissions and ongoing costs,

388 neither the regional processor nor the city retailer own their own premises. Thus, negotiations

389 with the building owners are required to set up a "green lease" where the lease agreement is

390 set up to recover costs of the solar panels (Council of Australian Governments (COAG)

391 National Strategy on Energy Efficiency, 2012). Despite these barriers, installation of solar

392 panels will result in long term lower energy costs and reduced GHG in both the regional

393 processor and city retailer.

394 Although replacing refrigeration equipment will also reduce current GHG emissions, the cost 395 of replacing equipment so soon after installing R404a equipment is a large barrier. Therefore, 396 it is recommended both supply chains continue (or increase) their refrigeration maintenance 397 to reduce refrigerant leakage and prevent further GHG emissions.

398 Despite the quantity of waste disposed in landfill, it had a minimal GHG impact in both 399 supply chains compared to electricity consumption. Although a potential profit can be made 400 from recycling this waste, it will only reduce GHG emissions up to 5.0\%. Thus, further 401 research into the profit potential of recycling is recommended only for solid waste reduction 402 purposes as opposed to potential GHG savings.

\section{Conclusions and Recommendations}

404 This research was unique as it measured the GHG emissions in finfish production from a 405 whole of chain perspective in Western Australia and included both refrigerants and fish waste 406 emissions.

407 Electricity had the greatest GHG emissions in both supply chains (78\% in the regional supply 408 chain and 93\% in the city supply chain). These emissions may be reduced by installing solar 409 panels at the regional processor and the city retailer, resulting in a potential $17.1 \%$ and $21.3 \%$ 410 respectively.

411 Other potential CPS discussed in this study (biogas production, refrigeration gas modification 412 and recycling filleting waste) had minimal reduction in GHG emissions, but when combined 413 with solar, a potential $38.6 \%$ and $25.7 \%$ from the regional and city supply chains respectively 414 could be prevented. 
415 The possible uses from recycling waste have been modelled include using all the waste to 416 create fertiliser or hydrolysate. Using all the waste (including heads, skin, viscera and frames) 417 instead of portions only, provides the best potential of reducing the GHG emissions by $6.0 \%$ 418 and $1.2 \%$ from the regional and city supply chains respectively. Further research is required 419 to model the effects of these recommendations in Western Australia.

420 Finally, the outcomes of this research will assist in the enhancement of the framework of the 421 seafood supply chain by enabling stakeholders, including similar Western Australian finfish 422 companies to restructure the supply chain with reduced GHG emissions by implementing 423 CPS. 
Andersen, O., 2002. Transport of fish from Norway: energy analysis using industrial ecology as the framework. Journal of Cleaner Production 10, 581-588.

Aspmo, S.I., Horn, S.J., H. Eijsink, V.G., 2005. Enzymatic hydrolysis of Atlantic cod (Gadus morhua L.) viscera. Process Biochemistry 40, 1957-1966.

Australian Industry Group, 2011. A supply chain based approach to Carbon Abatement: Pilot Study, http://pdf.aigroup.asn.au/environment/Public_report_web.pdf.

Barber, A., Pellow, G., 2006. Life Cycle Assessment: New Zealand Merino Industry Merino Wool Total Energy Use and Carbon Dioxide Emissions.

Berenbold, H., Kosswig, K., 1995. A life-cyle inventory for the production of secondary alkane sulphonate (SAS) in Europe. Tenside, Surfactants, Detergents 32, 152-156.

Bezama, A., Valeria, H., Correa, M., Szarka, N., 2012. Evaluation of the environmental impacts of a Cleaner Production Agreement by frozen fish facilities in the Biobío Region, Chile. Journal of Cleaner Production 26, 95-100.

Bhaskar, N., Mahendrakar, N.S., 2008. Protein hydrolysate from visceral waste proteins of Catla (Catla catla): optimization of hydrolysis conditions for a commercial neutral protease. Bioresource Technology 99, 4105-4111.

Bishai, M., De, S., Adhikari, B., Banerjee, R., 2013. Zizyphus oenophlia: A potent substrate for lactic acid production. Bioresource Technology 133, 627-629.

Biswas, W.K., Graham, J., Kelly, K., John, M.B., 2010. Global warming contributions from wheat, sheep meat and wool production in Victoria, Australia - a life cycle assessment. Journal of Cleaner Production 18, 1386-1392.

BOM, 2013. Climate statistics for Australian locations. Bureau of Meteorology, http://www.bom.gov.au/climate/data/index.shtml?bookmark=200.

Büsser, S., Jungbluth, N., 2009. The role of flexible packaging in the life cycle of coffee and butter. International Journal of Life Cycle Assessment 14, 80-91. Clean Energy Council, 2013. Clean Energy Australia Report 2012, http://www.cleanenergycouncil.org.au/policy-advocacy/reports/clean-energy-australiareport.html.

Coley, D., Howard, M., Winter, M., 2011. Food miles: time for a re-think? British Food Journal 113, 919-934.

Council of Australian Governments (COAG) National Strategy on Energy Efficiency, 2012. Tenant's Guide to Green Leases, http://industry.gov.au/Energy/EnergyEfficiency/NonresidentialBuildings/Documents/glsTenantsGuide.pdf.

Curry, N., Pillay, P., 2012. Biogas prediction and design of a food waste to energy system for the urban environment. Renewable Energy 41, 200-209.

Davidsson, A., Gruvberger, C., Christensen, T.H., Hansen, T.L., Jansen, J., 2007. Methane yield in source-sorted organic fraction of municipal solid waste. Waste Management 27, 406414.

Department of Fisheries, 2012. Status reports of the fisheries and aquatic resources of Western Australia 2011/12: The state of the fisheries. Department of Fisheries, http://www.fish.wa.gov.au/Documents/sofar/status_reports_of_the_fisheries_and_aquatic_res ources_2011-12.pdf.

Department of Sustainability Environment Water Population and Communities, 2012. Import Levy and Equivalent Carbon Price Calculator.

Department of the Environment, National Greenhouse Gas Inventory, http://ageis.climatechange.gov.au/SGGI.aspx\# 
Ellingsen, H., Aanondsen, S.A., 2006. Environmental impacts of wild caught cod and farmed salmon - A comparison with chicken. International Journal of Life Cycle Assessment 11, 6065.

474 Ellingsen, H., Olaussen, J.O., Utne, I.B., 2009. Environmental analysis of the Norwegian fishery and aquaculture industry - A preliminary study focusing on farmed salmon. Marine

476 Policy 33, 479-488. Engelbrecht, D., Biswas, W.K., Ahmad, W., 2013. An evaluation of integrated spatial technology framework for greenhouse gas mitigation in grain production in Western Australia. Journal of Cleaner Production 57, 69-78.

480 Esteban, M.B., Garcia, A.J., Ramos, P., Marquez, M.C., 2007. Evaluation of fruit-vegetable and fish wastes as alternative feedstuffs in pig diets. Waste Management 27, 193-200. Forster, P., Ramaswamy, V., Artaxo, P., Berntsen, T., Betts, R., Fahey, D.W., Haywood, J., Lean, J., Lowe, D.C., Myhre, G., Nganga, J., Prinn, R., Raga, G., Schulz, M., Dorland, R.V., 2007. Changes in Atmospheric Constituents and in Radiative Forcing, in: Solomon, S., Qin, D., Manning, M., Chen, Z., Marquis, M., Averyt, K.B., M.Tignor, Miller, H.L. (Eds.), Climate Change 2007: The Physical Science Basis. Contribution of Working Group I to the Fourth Assessment Report of the Intergovernmental Panel on Climate Change. Cambridge University Press, Cambridge, United Kingdom and New York, NY, USA.

Greene, J.W., 1996. Incorporation of pollution prevention principles into chemical science education, Department of Environmental and Industrial Health. University of Michigan. Gunady, M.G.A., Biswas, W., Solah, V.A., James, A.P., 2012. Evaluating the global warming potential of the fresh produce supply chain for strawberries, romaine/cos lettuces (Lactuca sativa), and button mushrooms (Agaricus bisporus) in Western Australia using life cycle assessment (LCA). Journal of Cleaner Production 28, 81-87.

Gupta, S., Palsule-Desai, O.D., 2011. Sustainable supply chain management: Review and research opportunities. IIMB Management Review 23, 234-245.

Hapsari Budisulistiorini, S., 2007. Life cycle assessment of paper towel and electric dryer as hand drying method in the University of Melbourne. Jurnal Teknik 28, 132-141. Hoare, J.L., 1974. Wool-scouring Effluent Part II: Further Observations on the Use of Aliphatic Alcohols as Destabilizing Agents. Journal of The Textile Institute 65, 445-448. Hobday, A.J., Bustamante, R.H., Farmery, A., Fleming, A., Frusher, S., Green, B., Jennings, S., Lim-Camacho, L., Norman-Lopez, A., Pascoe, S., Pecl, G., Plagányi, E., Putten, I.v., Schrobback, P., Thebaud, O., Thomas, L., 2014. Growth opportunities and critical elements in the supply chain for wild fisheries and aquaculture in a changing climate, Final Report. FRDC-DCCEE Marine National Adaptation Program Hospido, A., Tyedmers, P., 2005. Life cycle environmental impacts of Spanish tuna fisheries. Fisheries Research 76, 174-186.

Hospido, A., Vazquez, M.E., Cuevas, A., Feijoo, G., Moreira, M.T., 2006. Environmental assessment of canned tuna manufacture with a life-cycle perspective. Resources,

Conservation and Recycling 47, 56-72.

511 ICF Consulting, 2003. The Use of Alternatives to Synthetic Greenhouse Gases in Industries

512 Regulated by the Montreal Protocol, in: Australian Greenhouse Office (Ed.). Australian

513 Greenhouse Office.

514 Ingwersen, W.W., 2012. Life cycle assessment of fresh pineapple from Costa Rica. Journal of Cleaner Production 35, 152-163. International Organisation for Standardization, 2006. ISO 14044:2006 Environmental management - life cycle assessment - requirements and guidelines, 1 ed. ISO, Geneva. Iribarren, D., Vázquez-Rowe, I., Hospido, A., Moreira, M.T., Feijoo, G., 2010. Estimation of the carbon footprint of the Galician fishing activity (NW Spain). Sci. Total Environ. 408, 5284-5294. 
Iribarren, D., Vázquez-Rowe, I., Hospido, A., Moreira, M.T., Feijoo, G., 2011. Updating the carbon footprint of the Galician fishing activity (NW Spain). Sci. Total Environ. 409, 16091611.

Khoddami, A., 2012. Quality and fatty acid profile of the oil extracted from fish waste (head, intestine and liver) (Euthynnus affinis). Afr. J. Biotechnol. 11.

Kim, S., Dale, B.E., 2003. Cumulative Energy and Global Warming Impact from the Production of Biomass for Biobased Products. Journal of Industrial Ecology 7, 147-162. Kissinger, M., 2012. International trade related food miles - The case of Canada. Food Policy 37, 171-178.

530 Lankey, R.L., McMichael, F.C., 2000. Life-Cycle Methods for Comparing Primary and

531 Rechargeable Batteries. Environmental Science and Technology 34, 2299-2304.

532 Life Cycle Strategies Pty Ltd, 2012. Australasian LCI database version 2012.7. Life Cycle

533 Strategies Pty Ltd, Melbourne.

534 López-Mosquera, M.E., Fernández-Lema, E., Villares, R., Corral, R., Alonso, B., Blanco, C., 2011. Composting fish waste and seaweed to produce a fertilizer for use in organic agriculture. Procedia Environmental Sciences 9, 113-117.

Lund, C., Biswas, W., 2008. A Review of the Application of Lifecycle Analysis to Renewable Energy Systems. Bulletin of Science, Technology \& Society 28, 200-209.

Ng, H.Y., 2010. WA Seafood Waste: Audit and identification of potential for utilization,

541 Nges, I.A., Mbatia, B., Björnsson, L., 2012. Improved utilization of fish waste by anaerobic

542 digestion following omega-3 fatty acids extraction. Journal of Environmental Management

$543110,159-165$.

544 Nolan-Itu Pty Ltd, 2002. Plastic Shopping Bags - Analysis of Levies and Environmental Impacts. Environment Australia.

Northern Prawn Fisheries, 2014. Addressing the urgent need to identify viable refrigerant alternatives for use in the Northern Prawn Fishery.

Parker, R.W.R., Tyedmers, P.H., 2012. Life Cycle Environmental Impacts of Three Products Derived from Wild-Caught Antarctic Krill (Euphausia superba). Environmental Science and Technology 46, 4958-4965.

Ramos, S., Vázquez-Rowe, I., Artetxe, I., Moreira, M., Feijoo, G., Zufía, J., 2011.

Environmental assessment of the Atlantic mackerel (Scomber scombrus) season in the Basque Country. Increasing the timeline delimitation in fishery LCA studies. International Journal of Life Cycle Assessment 16, 599-610.

Renouf, M., Wegener, M., Pagan, R., 2010. Life cycle assessment of Australian sugarcane production with a focus on sugarcane growing. International Journal of Life Cycle Assessment 15, 927.

Renouf, M.A., Fujita-Dimas, C., 2013. Application of LCA in Australia agriculture - a review, The 8th Life Cycle Assessment Conference, Manly, Australia.

560 Saeki, Y., Emura, T., 2002. Technical progresses for PVC production. Progress in Polymer 561 Science 27, 2055-2131.

562 Sanjuan, N., Stoessel, F., Hellweg, S., 2014. Closing data gaps for LCA of food products: 563 estimating the energy demand of food processing. Environmental Science and Technology 564 48, 1132-1140.

565 Schau, E.M., Ellingsen, H., Endal, A., Aanondsen, S.A., 2009. Energy consumption in the Norwegian fisheries. Journal of Cleaner Production 17, 325-334.

Svanes, E., Vold, M., Hanssen, O., 2011a. Effect of different allocation methods on LCA results of products from wild-caught fish and on the use of such results. International Journal of Life Cycle Assessment 16, 512-521. 

from autoline fisheries. International Journal of Life Cycle Assessment 16, 611-624. Sydney Fish Market, 2013. Sydney Fish Market Pty Ltd Annual Report 2013. Symons, G.E., Buswell, A.M., 1933. The Methane Fermentation of Carbohydrates1,2. J. Am. Chem. Soc. 55, 2028-2036.

Tassou, S., Ge, Y., 2008. Reduction of refrigeration energy consumption and environmental impacts in food retailing, in: Klemeš, J., Smith, R., Kim, J.K. (Eds.), Handbook of Water and Energy Management in Food Processing. Woodhead Publishing. The Australian Institute of Refrigeration, Airconditioning and Heating, 2012. Methods of calculating Total Equivalent Warming Impact (TEWI) 2012, in: AIRAH (Ed.), Best Practice Guidelines.

581 Thrane, M., 2004. Energy Consumption in the Danish Fishery: Identification of Key Factors. Journal of Industrial Ecology 8, 223-239.

583

584 Thrane, M., 2006. LCA of Danish Fish Products. New methods and insights. International Journal of Life Cycle Assessment 11, 66.

Tlusty, M.F., Lagueux, K., 2009. Isolines as a new tool to assess the energy costs of the production and distribution of multiple sources of seafood. Journal of Cleaner Production 17, 408-415.

UNEP, 2002. Changing production patterns - learning from the experience of national cleaner production centre, Paris.

590 van Berkel, R., 2007. Cleaner production and eco-efficiency initiatives in Western Australia 591 1996-2004. Journal of Cleaner Production 15, 741-755.

592 Vázquez-Rowe, I., Iribarren, D., Hospido, A., Moreira, M.T., Feijoo, G., 2011a. Computation of operational and environmental benchmarks within selected galician fishing fleets. Journal of Industrial Ecology 15, 776-795.

Vázquez-Rowe, I., Iribarren, D., Moreira, M.T., Feijoo, G., 2010a. Combined application of life cycle assessment and data envelopment analysis as a methodological approach for the assessment of fisheries. International Journal of Life Cycle Assessment 15, 272-283. Vázquez-Rowe, I., Moreira, M.T., Feijoo, G., 2010b. Life cycle assessment of horse mackerel fisheries in Galicia (NW Spain): Comparative analysis of two major fishing methods. Fisheries Research 106, 517-527.

601 Vázquez-Rowe, I., Moreira, M.T., Feijoo, G., 2011b. Life Cycle Assessment of fresh hake 602 fillets captured by the Galician fleet in the Northern Stock. Fisheries Research 110, 128-135. Vázquez-Rowe, I., Moreira, M.T., Feijoo, G., 2012. Environmental assessment of frozen common octopus (Octopus vulgaris) captured by Spanish fishing vessels in the Mauritanian EEZ. Marine Policy 36, 180-188.

Vázquez-Rowe, I., Villanueva-Rey, P., Mallo, J., De la Cerda, J.J., Moreira, M.T., Feijoo, G., 2013. Carbon footprint of a multi-ingredient seafood product from a business-to-business perspective. Journal of Cleaner Production 44, 200-210.

Vink, E.T.H., Davies, S., Kolstad, J.J., 2010. The eco-profile for current Ingeo® polylactide production. Industrial Biotechnology 6, 212-224.

Vink, E.T.H., Rábago, K.R., Glassner, D.A., Gruber, P.R., 2003. Applications of life cycle assessment to NatureWorks ${ }^{\mathrm{TM}}$ polylactide (PLA) production. Polymer Degradation and Stability 80, 403-419.

Williams, H., Wikström, F., 2011. Environmental impact of packaging and food losses in a life cycle perspective: a comparative analysis of five food items. Journal of Cleaner Production 19, 43-48.

Winther, U., Ziegler, F., Skontorp Hognes, E., Emanuelsson, A., Sund, V., Ellingsen, H., 2009. Carbon footprint and energy use of Norwegian seafood products. SINTEF. 
619 Ziegler, F., Emanuelsson, A., Eichelsheim, J.L., Flysjö, A., Ndiaye, V., Thrane, M., 2011. 620 Extended Life Cycle Assessment of Southern Pink Shrimp Products Originating in

621 Senegalese Artisanal and Industrial Fisheries for Export to Europe. Journal of Industrial

622 Ecology 15, 527-538.

623 Ziegler, F., Hansson, P.A., 2003. Emissions from fuel combustion in Swedish cod fishery.

624 Journal of Cleaner Production 11, 303-314.

625 Ziegler, F., Nilsson, P., Mattsson, B., Walther, Y., 2003. Life Cycle assessment of frozen cod 626 fillets including fishery-specific environmental impacts. International Journal of Life Cycle 627 Assessment 8, 39.

628 Ziegler, F., Winther, U., Hognes, E.S., Emanuelsson, A., Sund, V., Ellingsen, H., 2013. The 629 Carbon Footprint of Norwegian Seafood Products on the Global Seafood Market. Journal of 630 Industrial Ecology 17, 103-116.

631

632 
634 Table 1 Studies of various harvest methods

635 Table 2 Categories of inputs and outputs in the supply chains measured

636 Table 3 Emission factors used

637 Table 4 Inventory differences between supply chains

638 Table 5 Monte Carlo Simulation uncertainty analysis (1,000 runs)

639 Table 6 Potential biogas yield in $\mathrm{kg}$ per functional unit

640 
Table 1 Studies of various harvest methods

\begin{tabular}{lll}
\hline Harvest method & Country & Reference \\
\hline Trawl harvested fish & Spain & (Iribarren et al., 2010; Iribarren et al., 2011; Ramos et al., 2011; Vázquez-Rowe \\
& et al., 2010a) \\
& $\begin{array}{l}\text { Denmark } \\
\text { Norway }\end{array}$ & $\begin{array}{l}\text { (Ellingsen and Aanondsen, 2006; Schau et al., 2009) } \\
\text { (Ellingsen and Aanondsen, 2006; Schau et al., 2009) }\end{array}$ \\
& Antarctic & (Parker and Tyedmers, 2012) \\
& Spain & (Hospido and Tyedmers, 2005) \\
Purse seine & Denmark & (Thrane, 2004) \\
& Norway & (Schau et al., 2009; Svanes et al., 2011a, b) \\
& Spain & (Iribarren et al., 2010) \\
Multiple methods within a & Norway & (Schau et al., 2009) \\
& & \\
fleet & Denmark & (Thrane, 2006) \\
& Spain & (Vázquez-Rowe et al., 2011a; Vázquez-Rowe et al., 2010b, 2011b) \\
& Senegal & (Ziegler et al., 2011) \\
& Sweden & (Ziegler and Hansson, 2003; Ziegler et al., 2003) \\
\hline
\end{tabular}

642

643 
Table 2 Categories of inputs and outputs in the supply chains measured

\begin{tabular}{|c|c|c|c|}
\hline & Unit per tonne of fish fillet & Regional Supply Chain & City Supply Chain \\
\hline \multicolumn{4}{|l|}{ Consumable Items } \\
\hline Carton liners & $\mathrm{kg}$ & 14.400 & 0.003 \\
\hline Checkout paper bags & $\mathrm{kg}$ & 53.156 & \\
\hline Checkout plastic bags & $\mathrm{kg}$ & & 14.988 \\
\hline Detergent & $\mathrm{kg}$ & 17.026 & 10.479 \\
\hline Esky & $\mathrm{kg}$ & 81.304 & \\
\hline Fillet covers & $\mathrm{kg}$ & 13.893 & 8.960 \\
\hline Grease & $\mathrm{kg}$ & 0.310 & 0.310 \\
\hline Hand sanitiser & $\mathrm{kg}$ & 6.219 & 0.833 \\
\hline Hand soap & $\mathrm{kg}$ & 3.110 & 0.957 \\
\hline Hydraulic oil & $\mathrm{kg}$ & 1.267 & 1.267 \\
\hline Lanolin grease & $\mathrm{kg}$ & 0.001 & 0.001 \\
\hline Lug buckets/tubs & $\mathrm{kg}$ & 7.724 & 7.724 \\
\hline Pallet wrap & $\mathrm{kg}$ & 0.114 & 0.114 \\
\hline Paper to wrap purchase & $\mathrm{kg}$ & 47.841 & 177.778 \\
\hline Paper towels & $\mathrm{kg}$ & 14.222 & 20.741 \\
\hline Plastic bag for fillet & $\mathrm{kg}$ & 13.821 & 14.815 \\
\hline Polypropylene bags & $\mathrm{kg}$ & 2.038 & 2.038 \\
\hline Rope & $\mathrm{kg}$ & 1.097 & 1.097 \\
\hline Rust rinse & $\mathrm{kg}$ & 4.026 & 4.026 \\
\hline Thick gloves & $\mathrm{kg}$ & 0.301 & 0.301 \\
\hline Water & $\mathrm{kg}$ & 45208.487 & 2849.003 \\
\hline \multicolumn{4}{|l|}{ Energy } \\
\hline Electricity & $\mathrm{kWh}$ & 13918.228 & 91509.972 \\
\hline Diesel & $\mathrm{kg}$ & 2851.156 & 2851.156 \\
\hline \multicolumn{4}{|l|}{ Transport } \\
\hline Ship & $\mathrm{tkm}$ & 153.493 & 153.493 \\
\hline Articulated truck & $\mathrm{tkm}$ & 741.508 & 101.148 \\
\hline Refrigerated articulated truck & $\mathrm{tkm}$ & & 3384.800 \\
\hline Rail & tkm & 60.505 & 5.934 \\
\hline Light commercial vehicle & $\mathrm{km}$ & 470.838 & 396.533 \\
\hline \multicolumn{4}{|l|}{ Storage } \\
\hline $\mathrm{R} 404 \mathrm{a}$ refrigeration gas & $\mathrm{kg}$ & 4.483 & 8.325 \\
\hline \multicolumn{4}{|l|}{ Waste } \\
\hline Fish waste & $\mathrm{kg}$ & 1666.667 & 1666.667 \\
\hline Waste recovered from landfill & $\mathrm{kg}$ & 663.333 & 663.333 \\
\hline Energy recovered from waste & $\mathrm{kWh}$ & 502.264 & 502.264 \\
\hline
\end{tabular}




\begin{tabular}{|c|c|c|c|}
\hline & Unit & $\mathrm{kg} \mathrm{CO}_{2}-\mathrm{eq}$ & Reference \\
\hline \multicolumn{4}{|l|}{ Energy } \\
\hline Electricity & Per kWh & 0.916 & (Life Cycle Strategies Pty Ltd, 2012) \\
\hline Diesel & Per kg & 0.675 & (Life Cycle Strategies Pty Ltd, 2012) \\
\hline Batteries & Per kg & 22.98 & $\begin{array}{l}\text { (Lankey and McMichael, 2000; Life Cycle Strategies Pty Ltd, } \\
\text { 2012) }\end{array}$ \\
\hline \multicolumn{4}{|l|}{ Transport } \\
\hline Ship & Per tkm & 0.02076 & (Life Cycle Strategies Pty Ltd, 2012) \\
\hline Articulated truck & Per tkm & 0.1002 & (Life Cycle Strategies Pty Ltd, 2012) \\
\hline $\begin{array}{l}\text { Refrigerated articulated } \\
\text { truck }\end{array}$ & Per tkm & & (Life Cycle Strategies Pty Ltd, 2012; Tassou and Ge, 2008) \\
\hline Rail & Per tkm & 0.0008760 & (Life Cycle Strategies Pty Ltd, 2012) \\
\hline $\begin{array}{l}\text { Light commercial } \\
\text { vehicle }\end{array}$ & Per km & 0.4402 & (Life Cycle Strategies Pty Ltd, 2012) \\
\hline \multicolumn{4}{|l|}{ Storage } \\
\hline $\mathrm{R} 404 \mathrm{a}$ refrigeration gas & Per kg & 3260 & $\begin{array}{l}\text { (Department of Sustainability Environment Water Population } \\
\text { and Communities, 2012) }\end{array}$ \\
\hline \multicolumn{4}{|l|}{ Waste } \\
\hline Fish Waste & Per kg & 1.39 & $\begin{array}{l}\text { (Curry and Pillay, 2012; Davidsson et al., 2007; Esteban et al., } \\
\text { 2007; Khoddami, 2012; Ng, 2010; Symons and Buswell, 1933) }\end{array}$ \\
\hline \multicolumn{4}{|l|}{ Consumable Items } \\
\hline Carton liners & Per kg & 1.949 & (Nolan-Itu Pty Ltd, 2002) \\
\hline Checkout paper bags & Per kg & 0.5327 & (Nolan-Itu Pty Ltd, 2002) \\
\hline Checkout plastic bags & Per kg & 1.949 & (Nolan-Itu Pty Ltd, 2002) \\
\hline Disposable gloves & Per kg & 0.5572 & \\
\hline Detergent regional & Per kg & 0.5193 & (Life Cycle Strategies Pty Ltd, 2012) \\
\hline Detergent city & Per kg & 0.1342 & (Life Cycle Strategies Pty Ltd, 2012) \\
\hline Esky & Per kg & 6.4136 & (Life Cycle Strategies Pty Ltd, 2012) \\
\hline Fillet covers & Per kg & 0.5572 & (Life Cycle Strategies Pty Ltd, 2012; Saeki and Emura, 2002) \\
\hline Grease & Per kg & 0.3890 & (Life Cycle Strategies Pty Ltd, 2012) \\
\hline Hand sanitiser & Per kg & 0.3819 & $\begin{array}{l}\text { (Kim and Dale, 2003; Life Cycle Strategies Pty Ltd, 2012; } \\
\text { Renouf et al., 2010) }\end{array}$ \\
\hline Hand soap & Per kg & 1.0170 & $\begin{array}{l}\text { (Bishai et al., 2013; Greene, 1996; Life Cycle Strategies Pty } \\
\text { Ltd, 2012; Renouf et al., 2010; Vink et al., 2010; Vink et al., } \\
\text { 2003) }\end{array}$ \\
\hline Hydraulic oil & Per kg & 0.4094 & (Life Cycle Strategies Pty Ltd, 2012) \\
\hline Lanolin grease & Per kg & 0.3885 & $\begin{array}{l}\text { (Barber and Pellow, 2006; Hoare, 1974; Life Cycle Strategies } \\
\text { Pty Ltd, 2012) }\end{array}$ \\
\hline Lug buckets/tubs & Per kg & 0.5572 & (Life Cycle Strategies Pty Ltd, 2012; Saeki and Emura, 2002) \\
\hline Pallet wrap & Per kg & 2.532 & (Nolan-Itu Pty Ltd, 2002) \\
\hline Paper to wrap purchase & Per kg & 0.5327 & (Nolan-Itu Pty Ltd, 2002) \\
\hline Paper towels & Per kg & 0.4118 & (Hapsari Budisulistiorini, 2007) \\
\hline Plastic bag for fillet & Per kg & 2.532 & (Nolan-Itu Pty Ltd, 2002) \\
\hline Polypropylene bags & Per kg & 4.083 & (Nolan-Itu Pty Ltd, 2002) \\
\hline Rope & Per kg & 4.083 & (Nolan-Itu Pty Ltd, 2002) \\
\hline Rust rinse & Per kg & 1.084 & $\begin{array}{l}\text { (Berenbold and Kosswig, 1995; Life Cycle Strategies Pty Ltd, } \\
\text { 2012) }\end{array}$ \\
\hline Thick gloves & Per kg & 0.0002427 & (Saeki and Emura, 2002) \\
\hline Water & Per kg & 0.000317 & (Life Cycle Strategies Pty Ltd, 2012) \\
\hline
\end{tabular}




\begin{tabular}{|c|c|}
\hline Regional Supply Chain & City Supply Chain \\
\hline \multicolumn{2}{|l|}{ Consumable items } \\
\hline Water bill included the neighbouring firm's consumption & Water bill was just for the retail stage \\
\hline $\begin{array}{l}\text { Packaged fillets in polystyrene eskies for transporting to the } \\
\text { store }\end{array}$ & Filleted on site and had no reason to transport fillets \\
\hline Provided paper bags for customer's convenience & Provided plastic bags for customer's convenience \\
\hline Used less paper to wrap the fillets & Used more paper to wrap the fillets \\
\hline \multicolumn{2}{|l|}{ Energy } \\
\hline $\begin{array}{l}\text { Used electricity to support storage in both processing and } \\
\text { retail stages }\end{array}$ & $\begin{array}{l}\text { Only one supply chain stage consumed electricity, but } \\
\text { consumed } 6 \text { times the consumption of the regional supply } \\
\text { chain }\end{array}$ \\
\hline \multicolumn{2}{|l|}{ Transport } \\
\hline Fish travelled $20 \mathrm{~km}$ in refrigerated van & Refrigerated truck travelled over $2000 \mathrm{~km}$ \\
\hline Consumable items travelled over $2000 \mathrm{~km}$ to site & Consumable items purchased in city \\
\hline $\begin{array}{l}\text { Storage } \\
\text { Displays fillets bunched up in display cabinet using less } \\
\text { refrigeration gases per functional unit }\end{array}$ & $\begin{array}{l}\text { Spread fillets out in display cabinet using more refrigeration } \\
\text { gases per functional unit }\end{array}$ \\
\hline $\begin{array}{l}\text { Waste } \\
\text { No difference }\end{array}$ & \\
\hline
\end{tabular}


652 Table 5 Monte Carlo Simulation uncertainty analysis (1,000 runs)

\begin{tabular}{llll}
\hline & Mean & Standard Deviation & Standard Error of Mean \\
\hline Regional supply chain & 18,500 & 516 & 0.000884 \\
City supply chain & 92,600 & 3580 & 0.00122 \\
\hline
\end{tabular}

653

654 
Table 6 Potential biogas yield in kg per functional unit

\begin{tabular}{lllll}
\hline & Carbon dioxide & Methane & Ammonia & Hydrogen sulphide \\
\hline Amino acids & 166.00 & 64.89 & 36.00 & 3.08 \\
$\begin{array}{l}\text { Fatty acids } \\
\text { Carbohydrates }\end{array}$ & 56.36 & 46.93 & & \\
Total & 2.84 & 1.03 & 36.00 & 3.08 \\
\hline $\begin{array}{l}\text { Assuming } \mathbf{7 5 . 8 \%} \\
\text { digestion }\end{array}$ & 225.20 & 112.86 & $\mathbf{2 7 . 2 9}$ & $\mathbf{2 . 3 3}$ \\
\hline
\end{tabular}

656 


\section{Figures}

658 Figure 1 System boundaries of each seafood supply chain

659 Figure 2 GHG comparision between the harvest to regional retailer supply chain and the harvest to city

660

661 retailer supply chain

662 Figure 4 Distribution of GHG in the regional supply chain (left) and city supply chain (right)

663

Percentage reduction of GHG from installing solar panels, utilising biogas, changing the refrigerant, recycling waste and a combination of the four CPS listed

664 


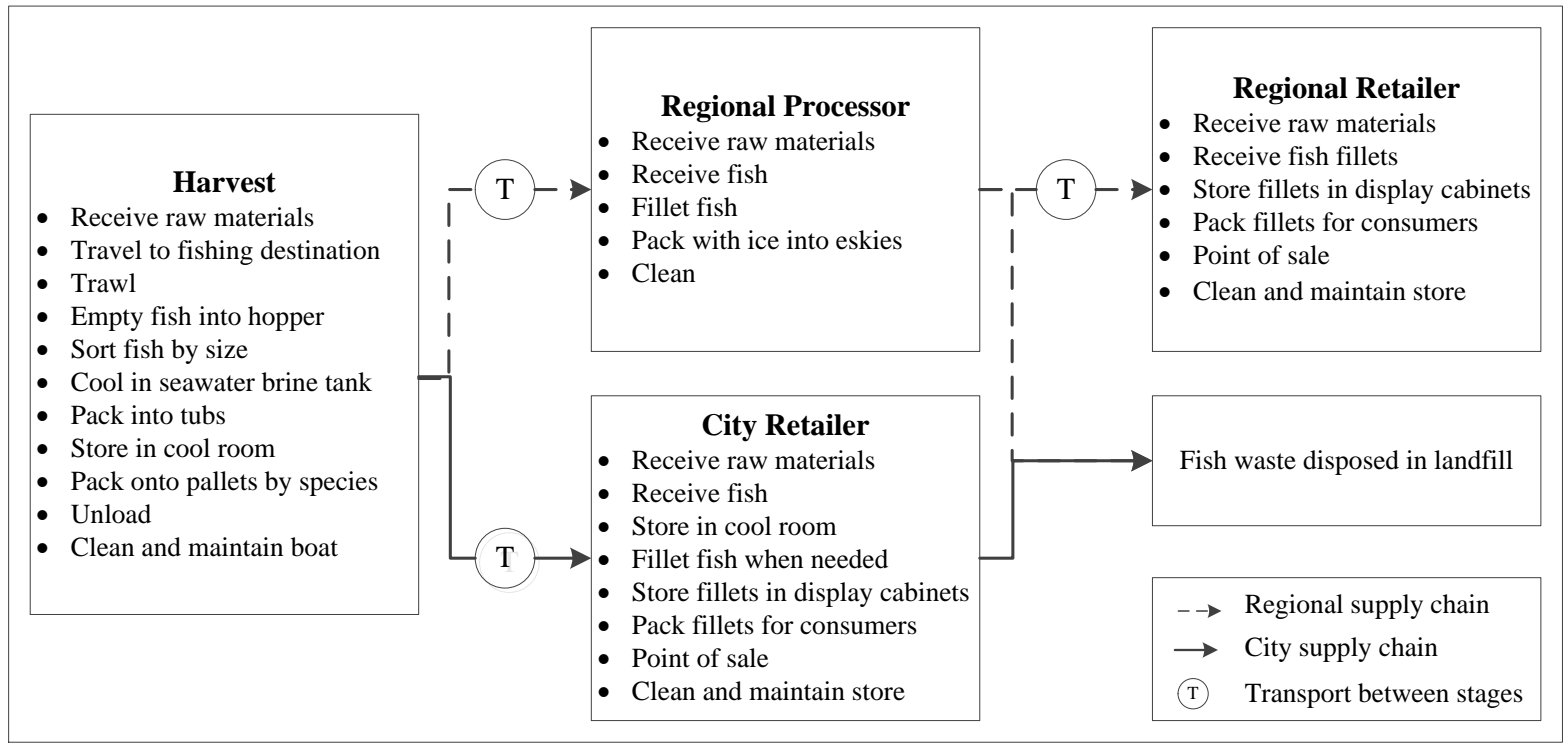


669

670

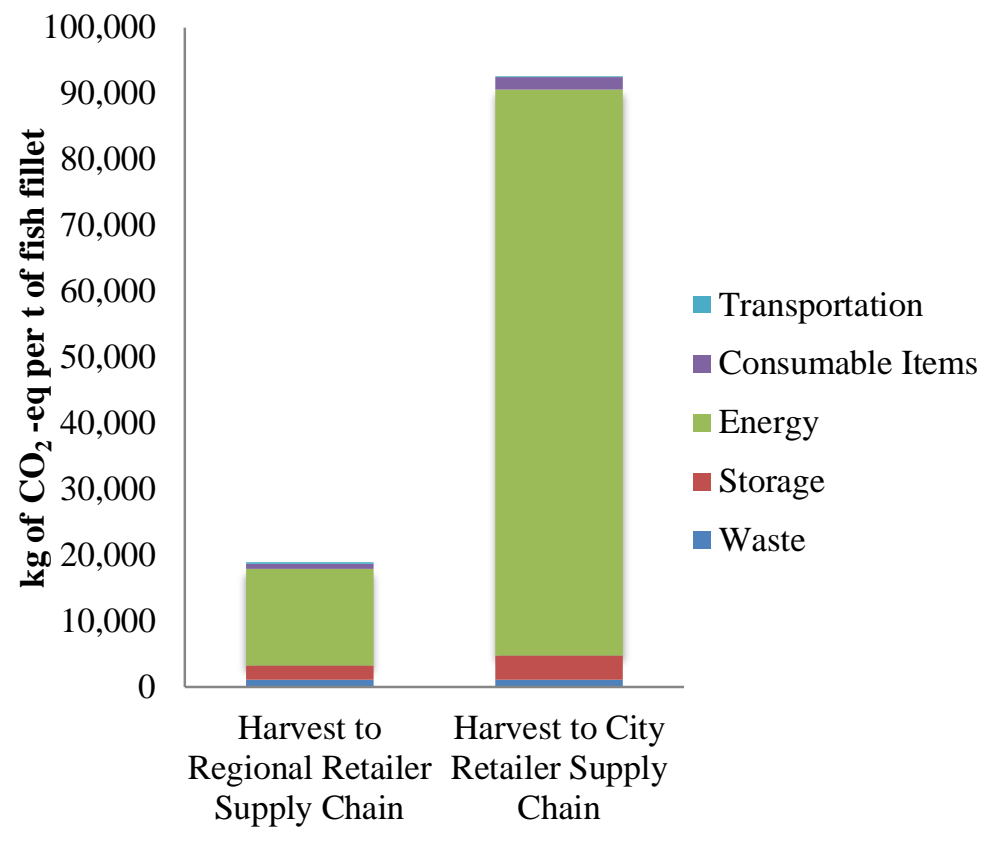

671 Figure 2 GHG comparision between the harvest to regional retailer supply chain and the harvest to city retailer 672 supply chain

673 
674

675
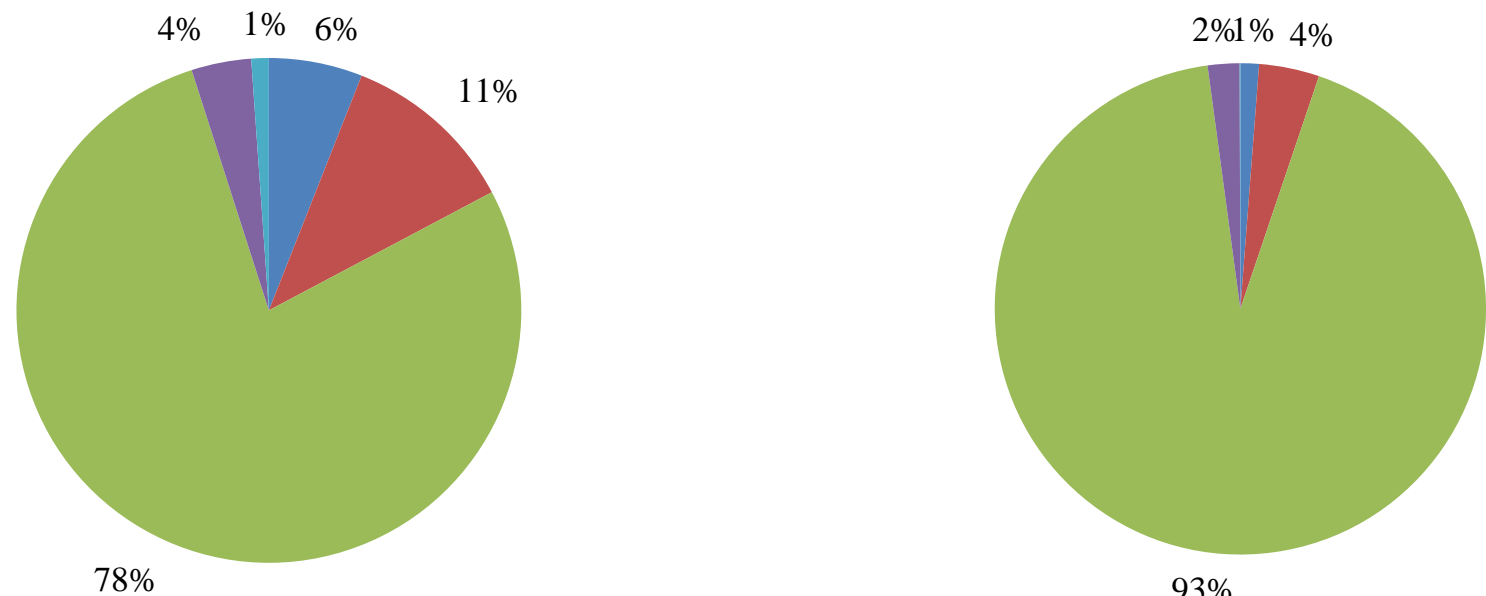

$93 \%$

$\square$ Waste $\square$ Storage Energy $\square$ Consumable Items $\square$ Transportation

676

677 Figure 3 Distribution of GHG in the regional supply chain (left) and city supply chain (right)

678 


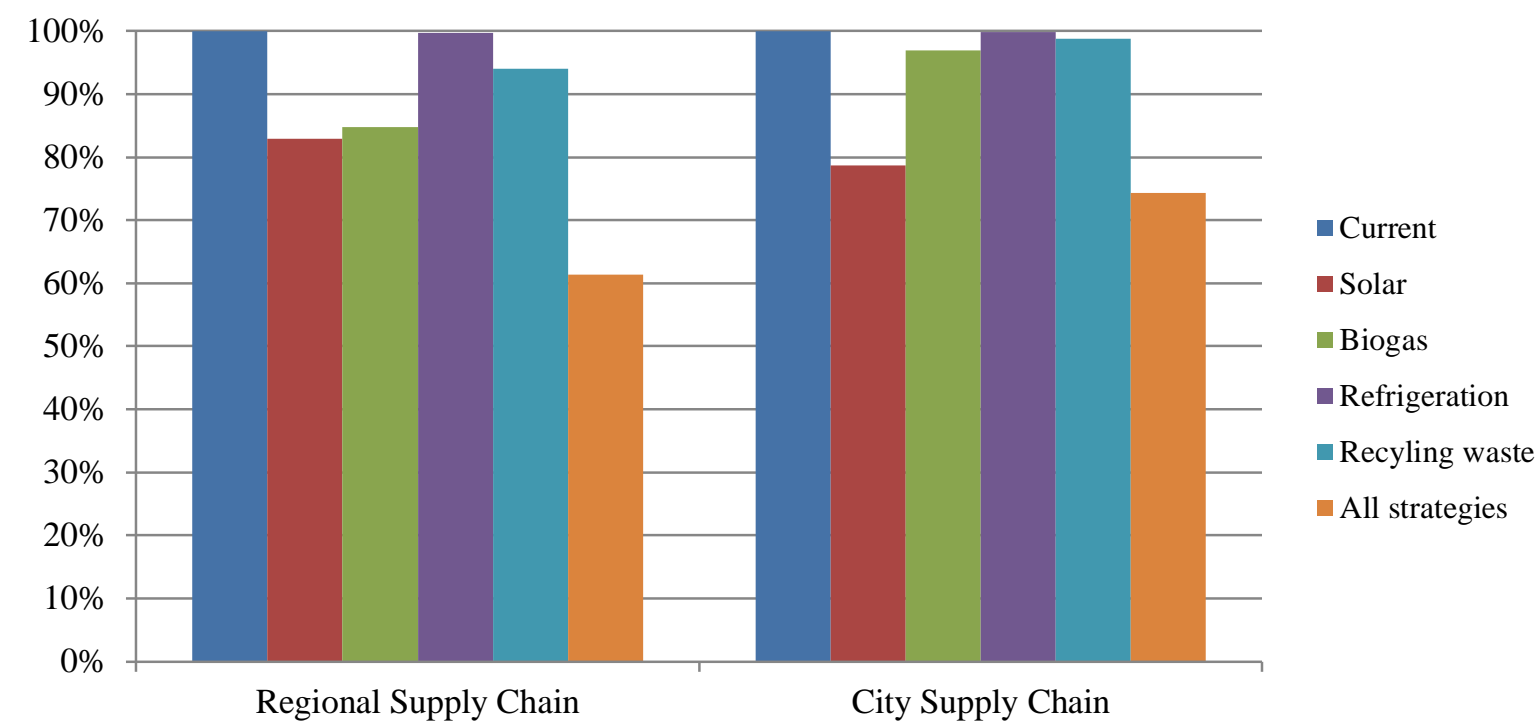

681 Figure 4 Percentage reduction of GHG from installing solar panels, utilising biogas, changing the refrigerant, 682 recycling waste and a combination of the four CPS listed

683 


\section{8. Acknowledgements}

685 The authors would like to thank Mrs Sue Denham for her assistance in editing. This project 686 was funded through a Curtin University PhD scholarship. Further funding for travel to collect 687 the data was provided by the Australian Seafood Co-operative Research Centre. 